\title{
犬体内での犬コロナウイルス増殖に及ぼす デキサメサゾンの影響
}

国分輝秋 ${ }^{1)}$ 田原口智士 ${ }^{1)}$ 畑野元子 ${ }^{1)}$ 高橋拓男 ${ }^{1)}$ 岩本かよ ${ }^{1)}$

増淵勝夫 ${ }^{1)}$ 山中盛正 ${ }^{1)}$ 佐々木 修 ${ }^{1)}$ 稲葉右二2)

1）(㑣微生物化学研究所（开611-0041 宇治市槇島町 24-16）

2）日本大学生物資源科学部獣医伝染病学教室（开252-0813 藤沢市亀井野 1866）

(1997 年 7 月 30 日受付・1998 年 4 月 8 日受理)

要約

犬コロナウイルス (CCV) 5821 株を十二指腸内，静脈内あるいは気管内に接種された犬にデキサメサゾン (DEX) を 投与し，ウイルスの体内増殖に及ぼす DEX の影響を検討した．十二指腸内あるいは静脈内接種例では，DEX 非投与 群の胃・大腸から CCV は検出されなかったが, DEX 投与群で胃・大腸・腸間膜リンバ節などから CCV が検出された. 十二指腸内接種後長期間飼育した DEX 投与群では, 水様下媊が観察され, 蕒便と血液から CCV が検出された. 気管 内接種例では DEX 投与の有無にかかわらず, 扁桃・肺・腸間膜リンパ節から CCV が検出されたが, 消化器からは検 出されなかった. 以上の成績から免疫機能が低下時には CCV が消化器で増殖する可能性が示唆された.

一キーワード:犬, コロナウイルス，デキサメサゾン.

一日獣会誌 51，516～519（1998）

犬コロナウイルス $(\mathrm{CCV})$ は下痢を呈した犬の粪便か ら分離され，犬への感染試験では小腸および大腸でウィ ルスが増殖し，糞便へ排出されることが報告されている $[3,4]$.

しかし，感染試験による下㢉の再現は一般に困難であ るか，あるいは下痢の程度が軽いことが多い $[2,9]$. Fulker ら [5]は，ワクチンの効果を評価するために，デ キサメサゾン $(\mathrm{DEX})$ を用いることによって CCV の感 染試験モデルを確立した．感染犬に DEX を投与すると 80\%の犬が重篤な下㢉を示し, 平均 10.8 病日であるこ とを報告している.

今回著者らは, 消化器よりも呼吸器に高い親和性を有 すると考えられる CCV 5821 株 $[1,7]$ の下痢症への関与 を知る目的で, DEX を用いて感染試験を実施した。

材料および方法

供試ウイルス：CCV 5821 株は犬腎細胞で 3 代，猫腎 由来株化細胞（CRFK 細胞）で 5 代継代したあのを用 いた.

感染試験：感染試験 1 では CCV 抗体陰性の約 2 力月 齢の犬 12 頭を用い， 4 頭ずつ 3 群に分け，十二指腸内, 静脈内または気管内に CCV 5821 株 $10^{7.25} \mathrm{TCID}_{50}$ を接種 した. 各群 4 頭中 2 頭にはウイルス接種前日から体重 1 $\mathrm{kg}$ あたり $1 \mathrm{mg}$ の $\mathrm{DEX}^{\mathrm{a})}$ を 3 日間連続で皮下に投与し た。 ウイルス投与 3 日後に剖検し, 扁桃, 気管, 肺, 肝
臟, 腎臓, 胃, 小腸, 大腸, 腸間膜リンパ節执よび脾臟 を採取して，10\%乳剤を作製した。これらの臓器乳剤と 剖検時に採取した直腸拭い液打よび脱線維素血液を用い てウイルス分離を行った。

感染試験 2 では約 4 力月齢の CCV 抗体陰性の犬 6 頭 を用い, 3 頭ずつ 2 群に分けて DEX 非投与群および投 与群とした. 各群 2 頭の十二指腸内に CCV 5821 株 $10^{7.25} \mathrm{TCID}_{50}$ を接種した. 各群 1 頭はウイルスを接種し ない同居対照犬とした。DEX 投与群ではウイルス接種 前日から 3 日間連続で体重 $1 \mathrm{~kg}$ あたり $1 \mathrm{mg}$ の DEX を 皮下に投与した.これらの犬についてウイルス接種後 3 週間にわたって, 食欲, 下媊および呼吸器症状を観察す るとともに, 直腸拭い液を採取し, また, 脱線維素血液 を接種後 $3 ， 6 ， 24 ， 48$ および 72 時間に採取した. 血清 についてはウイルス接種前と接種後 1,2 および 3 週に 採材した。

ウイルス分離：藏器の $10 \%$ 乳剂, 直腸拭い液または 糞便打よび脱線維素血液をウイルス分離材料とし, CRFK 細胞を用いて実施した [7].

抗体検查: 被検血清を $56^{\circ} \mathrm{C}, 30$ 分間非働化後中和試 験により実施し，CPE を指標に Reed-Muench 法 [8]に よって中和抗体価を算出した.

日獣会誌 $51 \quad 516 \sim 519 \quad$ (1998) 
国分輝秋 田原口智士 畑野元子 他

成 績

感染試験 1 の成績を表 1 に示した. CCV を十二指腸 内, 静脈内あるいは気管内接種した犬では, DEX 投与 の有無に関係なくいずれの接種経路でも腸間膜リンパ節 から CCV が検出された。 十二指腸内接種犬では, DEX 投与群においてのみ胃および大腸から CCV が検出され た. 静脈内接種犬では, DEX 非投与群において扁桃, 腸間膜リンパ節および 2 頭中 1 頭の脾臟から CCV が検 出されたが, DEX 投与群ではこれらの臟器に加えて胃, 大腸および腎臟からも CCV が検出された。気管内接種 犬では DEX 投与の有無にかかわらず，扁桃，肺および
腸間膜リンパ節から CCV が検出された。

感染試験 2 の成績を表 2 に示した。DEX 非投与群は $\mathrm{CCV}$ 接種後も臨床症状を示さず, 粪便および血液から $\mathrm{CCV}$ は検出されなかったが, 中和抗体価は $\mathrm{CCV}$ 接種 後 1 週から上昇した。一方, DEX 投与犬では DEX 投 与後 2 4 日間にわたって水様性の下淑を認め, 2 頭中 1 頭では CCV 接種後 9 日の糞便と 24 および 48 時間の血 液から，他の 1 頭では CCV 接種後 $11,13,14$ および 17 日の粪便と 24 時間の血液から CCV が検出された。 中和抗体は $\mathrm{CCV}$ 接種後 1 週から検出された。 同居対照 犬では糞便おょび血液から CCV は検出されなかったが, 中和抗体は同居 3 週目から検出された。

表 1 犬コロナウイルス 5821 株実験感染犬におけるウイルスの体内分布に及ぼすデキサメサゾン投与の影響 (感染試験 1 )

\begin{tabular}{|c|c|c|c|c|c|c|c|c|c|c|c|c|}
\hline \multirow{2}{*}{\multicolumn{2}{|c|}{$\begin{array}{l}\text { 供試犬'1) } \\
\text { 番 号 }\end{array}$}} & \multirow{2}{*}{\multicolumn{2}{|c|}{$\begin{array}{l}\text { ウイルス } \\
\text { ウ接種経路 }\end{array}$}} & \multirow{2}{*}{$\begin{array}{l}\text { デキサメサ } \\
\text { ゾン投与 }^{3)}\end{array}$} & \multicolumn{8}{|c|}{ 犬コロナウイルスの分離() } \\
\hline & & & & & 扁桃 & 肺 & 胃 & 大腸 & 腎 & 脾 & 腸間膜リンパ節 & 血液 \\
\hline & 1 & 十二 & 旨腸 & なし & -5) & - & - & - & - & - & $3.25^{6)}$ & - \\
\hline & 2 & 十二 & 旨腸 & なし & - & - & - & - & - & - & 2.75 & - \\
\hline & 3 & 十二 & 旨腸 & $1 \mathrm{mg} / \mathrm{kg}$ & - & - & 3.25 & 2.50 & - & - & 3.50 & - \\
\hline & 4 & 十二 & 旨腸 & $1 \mathrm{mg} / \mathrm{kg}$ & - & - & - & 2.25 & - & - & 3.75 & - \\
\hline & 5 & 静 & 脈 & なし & 2.75 & - & - & - & - & - & 4.50 & - \\
\hline & 6 & 静 & 脈 & なし & 3.00 & - & - & - & - & 2.00 & 4.00 & - \\
\hline & 7 & 静 & 脈 & $1 \mathrm{mg} / \mathrm{kg}$ & 2.75 & - & 2.75 & 3.00 & 2.75 & 3.00 & 5.25 & - \\
\hline & 8 & 静 & 脈 & $1 \mathrm{mg} / \mathrm{kg}$ & 2.5 & - & 3.25 & 2.50 & 2.75 & 2.75 & 5.00 & - \\
\hline & 9 & 気 & 管 & なし & 1.75 & 2.25 & - & - & - & - & 2.50 & - \\
\hline & 10 & 気 & 管 & なし & 2.00 & 2.50 & - & - & - & - & 3.00 & - \\
\hline & 11 & 気 & 管 & $1 \mathrm{mg} / \mathrm{kg}$ & 2.00 & 1.75 & - & - & - & - & 2.00 & - \\
\hline & 12 & 気 & 管 & $1 \mathrm{mg} / \mathrm{kg}$ & 1.75 & 2.00 & - & - & - & - & 1.75 & - \\
\hline \multicolumn{13}{|c|}{ 1) 生後約 2 カ月の犬コロナウイルス抗体陰性のビーグル犬 } \\
\hline \multicolumn{13}{|c|}{ 2) ウイルス接種量 $10^{7.25} \mathrm{TCID}_{50}$} \\
\hline \multicolumn{13}{|c|}{ 3) ウイルス接種の前日から 3 日間連続投与 } \\
\hline \multicolumn{13}{|c|}{ 4) ウイルス接種 3 日後に剖検・採材 } \\
\hline \multicolumn{13}{|c|}{ 5）陰性 } \\
\hline \multicolumn{13}{|c|}{ 6) $\log \mathrm{TCID}_{50} / \mathrm{m} l$} \\
\hline
\end{tabular}

表 2 犬コロナウイルス 5821 株実験感染犬の糞便ならびに血液からのウイルス検出と中和抗体価に及ぼす デキサメサゾン投与の影響（感染試験 2 ）

\begin{tabular}{|c|c|c|c|c|c|c|c|c|c|c|c|c|c|}
\hline \multirow{2}{*}{$\begin{array}{l}\text { 供試犬1) } \\
\text { 番 号 }\end{array}$} & \multirow{2}{*}{$\begin{array}{l}\text { ウイルス }{ }^{2)} \\
\text { 接種経路 }\end{array}$} & \multirow{2}{*}{$\begin{array}{l}\text { デキサメサ } \\
\text { ゾン投与 }\end{array}$} & \multirow{2}{*}{$\begin{array}{l}\text { 臨床 } \\
\text { 症状 }\end{array}$} & \multirow{2}{*}{$\begin{array}{l}\text { 糞便中の } \\
\text { ウイ }\end{array}$} & \multicolumn{5}{|c|}{ 血液中のウイルス } & \multicolumn{4}{|c|}{ 中和 抗 体 価 } \\
\hline & & & & & 3 & 6 & 24 & 48 & $72\left({\left.\text { (時間 })^{6}\right)}^{2}\right.$ & 前 & 1 & 2 & $3(\text { (週 })^{6)}$ \\
\hline 1 & 十二指腸 & なし & - & - & - & - & - & - & - & $<2$ & 8 & 128 & 1,024 \\
\hline 2 & 十二指腸 & なし & - & - & - & - & - & - & - & $<2$ & 4 & 128 & 715 \\
\hline 3 & 同居対照 & なし & - & - & - & - & - & - & - & $<2$ & $<2$ & $<2$ & $<2$ \\
\hline 4 & 十二指腸 & $1 \mathrm{mg} / \mathrm{kg}$ & + & $+(9)$ & - & - & + & + & - & $<2$ & 32 & 715 & 1,430 \\
\hline 5 & 十二指腸 & $1 \mathrm{mg} / \mathrm{kg}$ & + & $+(11,13,14,17)$ & - & - & + & - & - & $<2$ & 16 & 715 & 2,048 \\
\hline 6 & 同居対照 & $1 \mathrm{mg} / \mathrm{kg}$ & \pm & - & - & - & - & - & - & $<2$ & $<2$ & $<2$ & 64 \\
\hline \multicolumn{14}{|c|}{ 1) 生後約 4 カ月の犬コロナウイルス抗体陰性のビーグル犬 } \\
\hline \multicolumn{14}{|c|}{ 2) ウイルス接種量 $10^{7.25} \mathrm{TCID}_{50}$} \\
\hline \multicolumn{14}{|c|}{ 3) ウイルス接種の前日から 3 日間連続投与 } \\
\hline \multicolumn{14}{|c|}{ 4) - 異常なし；＋ 水様便；士 軟便 } \\
\hline \multicolumn{14}{|c|}{ 5)（）内はウイルスが検出されたウイルス接種後の日数 } \\
\hline \multicolumn{14}{|c|}{ 6)ウイルス接種後の時間または週 } \\
\hline
\end{tabular}




\section{犬体内での犬コロナウイルス増殖に及ぼすデキサメサゾンの影響}

$$
\text { 考察 }
$$

CCV は犬の胃腸炎の原因ウイルスであると考えられ ているが，感染試験では粪便からのウイルスの排出は認 められるあのの, 下痢, 脱水, 食欲不振などの臨床症状 の確実な再現は一般に困難であるとされている $[2,9]$. $\mathrm{CCV}$ 感染にともなう発病には感染犬の栄養状態やスト レス，犬パルボウイルスの混合感染などがその誘因とし て重要であると考えられている [3]. Fulker ら [5]は, CCV 1-71 株を経口投与後, DEX を 4 日間連続で投与 した犬では臨床症状が顕在化し, 下痢, 沈うつ, 脱水, 食欲不振，鼻漏，目やになどが認められるととあに，特 に血液を混じた激しい水様性下痢がみられることを報告 した.

一方，著者らが分離した CCV 5821 株は，子犬を用い た感染試験において呼吸器から高率に分離されたのに対 し，粪便からはいずれの投与経路においてあまったく検 出されなかった [7]．このことから，5821株は1-71 株 や他の CCV 株とは組織親和性や病原性が異なると考え られたので, 本研究では 5821 株の犬体内での増殖と発 病に及ぼす DEX の影響について検討した。

CCV 5821 株を静脈内接種した犬では，DEX 非投与 群において扁桃，腸間膜リンパ節および 2 頭中 1 頭の脾 臓から CCV が検出された。一方, DEX 投与群におい ては胃, 大腸, 腎臓, 脾臓および血液から検出されるよ うになり，CCVが血液を介して犬体内に広く分布した ことが確認された。著者らは, 生後 3 日の新生子犬に 5821 株を経口・経鼻接種した時, 2 頭中 1 頭が呼吸器症 状を示して死亡し, CCV が呼吸器から高率に検出され ることを報告した $[7]$. CCV 5821 株を気管内接種した 2 カ月齢の犬では, DEX 投与による感染性の増強は認め られず，呼吸器症状むみられなかった。したがって， 5821 株の呼吸器における感染や発病には犬の年龄が大 きく関与することが考えられた.

CCV 5821 株を十二指腸内に接種して DEX を連日投
与すると，胃や大腸で CCV が検出されるようになり， 粪便から屯 $\mathrm{CCV}$ が検出された。 しかし, 糞便からの $\mathrm{CCV}$ の検出時期は感染後 9 日以降で, 血中抗体価の上 昇後であった。一方，1-71 株は DEX を投与しない場合 でも下痢を 4 〜 日間示すとともに, CCV が糞便から 6〜9 日間検出されたと報告されている $[6] こ と か ら ，$ 5821 株の腸管増殖性は 1-71 株に比べて弱いあのと考え られた。

感染試験 2 において DEX を投与した犬では, CCV 接種後 2 日以降水様性の下痢が認められたが, CCV を 接種しない同居対照犬にもウイルスは検出されないもの の軽い下痢がみられた。したがって, 水様性下痢の原因 として CCV の感染だけでなく, DEX の投与も関与し たものと考えられた。

これらの成績から, CCV 5821 株は何らかの原因で犬 の免疫機能が低下した時, 消化器感染を起こす可能性が あることが示唆された.

なお，本試験は動物愛護の精神に基づき実施された。

\section{引用文 献}

［1］安食政幸, 国分輝秋, 田中雅之, 他: 第 97 回日本獣医 学会講演要旨集, 122 (1984)

[2] Appel, MJG : Virus Infections of Carnivores, Appel, MJG ed, 115-122, Elsevier, New York (1987)

[3] Appel, MJG : Vet Med, 83, 360-366 (1988)

[4] Binn LN, Lazer EC, Keenan KP, et al : Proc U.S. Anim Health Assoc, 78, 359-366 (1974)

[5] Fulker R, Wasmoen, T, Atchison, R, et al : Adv Exp Med Biol, 380, 229-234 (1995)

[6] Keenan KP, Jervis HR, Marchwicki RH, et al : Am J Vet Res, 37, 247-256 (1976)

[ 7 ] 国分輝秋, 田原口智士, 畑野元子, 他：日獣会誌， 51, 193-196 (1998)

[8] Reed LJ, Muench H, : Am J Hyg, 27, 493-497 (1938)

[9] Tennant BJ, Gaskell RM, Kelly DF, et al : Res Vet Sci, 51, 11-18 (1991) 
Effect of Dexamethasone on Canine Coronavirus Infection in Dogs Teruaki KOKUBU*, Satoshi TAHARAGUCHI, Motoko HATANO, Takuo TAKAHASHI, Kayo IWAMOTO, Katuo MASUBUCHI, Morimasa YAMANAKA, Osamu SASAKI and Yuji INABA

* Division of Veterinary Microbioiogy, Kyoto-Biken Loboratories, 24-16 Makisima, Uji 611-0041, Japan

\section{SUMMAY}

The effects of dexamethasone (DEX) were investigated in puppies inoculated with coronavirus (CCV), 5821 strain. In dogs inoculated intraduodenally or intravenously with $\mathrm{CCV}$, and treated with DEX, virus was detected from the stomach, large intestines and mesenteric lymph nodes, while no virus was detectable from the stomach and large intestines without DEX. Dogs which were reared for longer time period after intraduodenal inoculation plus DEX, developed watery diarrhea, and virus was recovered from blood and feces. In cases inoculated intratracheally with $\mathrm{CCV}$, the tonsil, lungs and mesenteric lymph nodes were positive for virus, irrespective of DEX administration. The results suggested that DEX might enhance the CCV infection in the digestive tract of dogs. - Key words : canine, coronavirus, dexamethasone.

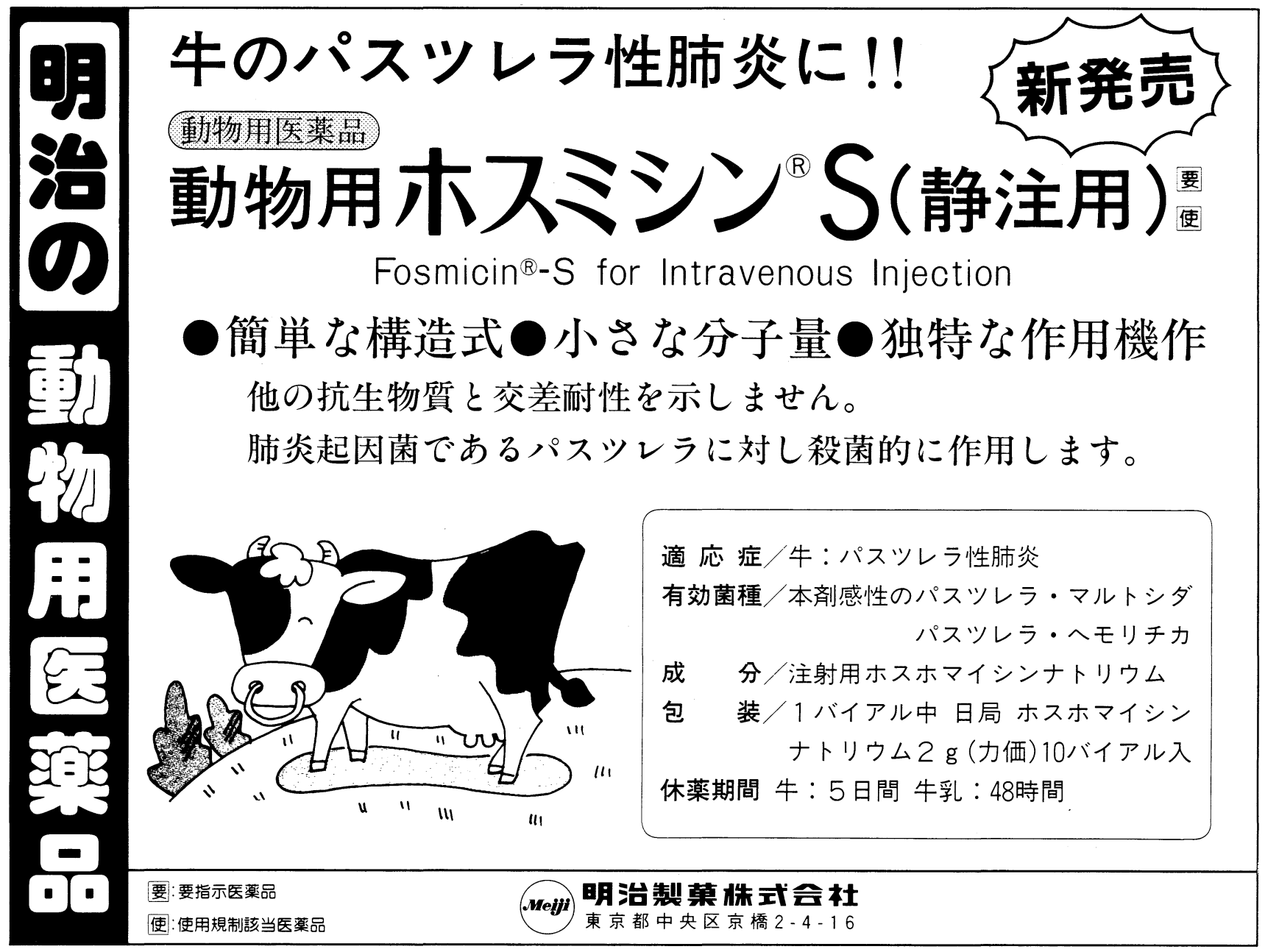

